\title{
THE FEDERAL VOTING REFEREE PLAN AND THE ALTERATION OF STATE VOTING STANDARDS
}

Possible legislation to combat voter discrimination can be considered in one of two categories. Such legislation can either recognize that state standards are being used to further discrimination and seek to eliminate them, alter them, or equate them with some easily provable requirement; or it can work within the presumption of nondiscriminatory state standards and seek to provicle procedural safeguards to ensure the validity of this presumption or remedies for discriminatory actions which belie the presumption. The distinction between these categories takes on significance from the fact that many observers believe that the first category of legislation falls outside the scope of federal authority, ${ }^{1}$ especially in respect to state elections. ${ }^{2}$ To date Congress has not enacted legislation which clearly falls in the first category and thus the scope of federal authority in the area of voter qualifications has yet to be defined. The voting referee plan ${ }^{3}$ of the Civil Rights Act of 1960,4 however, may raise this ques-

1. See, e.g., Hearings on S. 480, S. 2750, and S. 2979, Before the Subcommillec on Constitutional Rights of the Senate Committee on the Judiciary, 87th Cong., 2d Sess, at 576-79, 587-89, 614-26, 633-34, 634-35, 635-39 (1962). These hearings contain letters from constitutional law professors of 26 law schools giving opinions on the constitutionality of proposed legislation which would make a sixth grade education the equivalent of any state literacy requirement. A wide range of view was expressed, ranging from clear unconstitutionality to equally clear constitutionality.

[B]arring a constitutional amendment, the power of the states to determinte for themselves what the specific nondiscriminatory qualifications should be remains exclusively a state prerogative.

Id. at 588, 589. (Letter from Professor Donald J. Farage, Dickinson School of Law, to Senator Sam J. Ervin, March 27, 1962.)

The proposed legislation presents serious and substantial questions of constitutionality. It prescribes a drastic remedy at the expense of state power to prescribe a type of qualification which the Supreme Court has recognized as valid.

Id. at 635, 638. (Letter from Professor Paul G. Kauper, Michigan University Law School, to Senator Sam J. Ervin, Feb. 26, 1962.)

To me the measures seem clearly constitutional.

Id. at 627. (Letter from Professor Arthur E. Sutherland, Harvard University Law School, to Senator Sam J. Ervin, Feb. 26, 1962.)

2. In federal elections, the right to vote emanates from the federal constitution. Sce United States v. Classic, 313 U.S. 299, 315 (1941); Ex parte Yarbrough, 110 U.S. 651 (1884). Congress may restrict state action as to congressional elections

by the exercise of its powers to regulate elections under [Article I] $\$ 4$ and its more general power under Article I, § 8, clause 18 of the Constitution "to make all laws which shall be necessary and proper for carrying into execution the forcgoing powers."

United States v. Classic, supra at 315 . In state elections, only the right to be cxempt from discrimimation comes from the federal constitution. See, e.g., United States v. Cruikshank, 92 U.S. 542, 555-56 (1876) ; Pope v. Williams, 193 U.S. 621,632 (1904).

3. 74 Stat. 90 (1960), 42 U.S.C. § 1971 (e) (Supp. III, 1962).

4. 74 Stat. 86 (1960), amending 18 U.S.C. $\$ \S 837,1074,1509$; 20 U.S.C. $\S \S 241,640$; 42 U.S.C. $\$ \S 1971,1974(\mathrm{a})-1974(\mathrm{e}), 1975(\mathrm{~d})$. 
tion. Section $1971(e)^{5}$ authorizes federal district courts, or voting referees appointed by them, to issue qualification certificates ${ }^{\circ}$ to individuals qualified to vote under state law who have been denied registration by the local registrar pursuant to a pattern or practice. If the standards used by the local registrar, however, are less stringent than the state statutory requirements, the federal district court is directed to use the registrar's standards. Because this procedure authorizes the certification of voters whose qualifications fall below those provided in the state statute, this legislation, designed primarily as a procedural mechanism, appears to fall within the first category. If so, it would raise constitutional problems concerning the limits of federal power in an area traditionally governed by the states, the qualifications of the state electorate. ${ }^{7}$ However, a closer look at the operation of section 1971(e) in the context of these two categories of federal voter legislation may obviate the necessity of deciding this constitutional question.

In the past, discriminatory provisions of state voter qualification standards have contributed to the lack of Negro registration in southern states. ${ }^{8}$ Among

5. 74 Stat. 90 (1960), 42 U.S.C. $§ 1971$ (e) (Supp. III, 1962).

6. The only certificates so far issued under this plan are in East Carroll Parish, Louisiana.

\section{CERTIFICATE OF QUALIFICATION TO VOTE}

It is hereby certified that

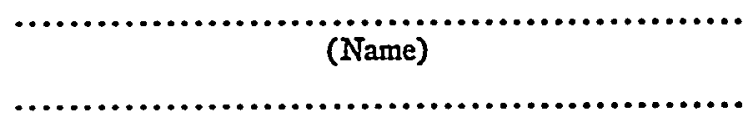

(Address)

who is affiliated with the .............. Party, has been declared qualified by Order of The United States District Court for the Western District of Louisiana to vote in Ward ......., Precinct ....... of .................... Parish, Louisiana.

United States District Judge

Date:

United States v. Manning, 206 F. Supp. 623, 624 (W.D. La. 1962).

7. See, e.g., Pope v. Williams, 193 U.S. 621 (1904).

8. Other factors also account for this low level of Negro registration:

Apathy is part of the answer. In Atlanta... Negroes can register freely and 29 percent have done so, but 44 percent of the whites have registered. . . Gallup polls indicate that outside the South the voting turnout of Negroes is less than that of whites; according to the Gallup surveys an average of 53 percent of Negroes voled in the four national elections from 1948 to 1954, compared with a white average of 61 percent. Such apathy may stem from lack of economic, educational, or other opportunities, but it does not constitute a denial of the right to vote.

RepoRt OF The UnIted States Coanitssion on Crvis. Rigits, 1959 at 52 (hereinafter cited as 1959 Conrarrssion Reporr). See also Bickel, Ciril Rights The Kennedy Record, The New Republic, December 15, 1962, p. 11.

The heart of the matter may be apathy, born of poverty, ignorance, and consequent passive alienation. . . . it may be-there is evidence in the North to support this 
these provisions were the infamous grandfather clauses ${ }^{0}$ and their derivatives. ${ }^{10}$ When these devices were struck down by the Supreme Court, many states resorted to standards which, although nondiscriminatory on their face, left much room for unequal application. And in fact, under these current state standards, massive discrimination continues against Negroes who wish to register to vote. ${ }^{11}$ But except where the criteria were so extremely vague as to invite discriminatory application, ${ }^{12}$ the Supreme Court has consistently declined to invalidate these standards merely because of the possibility that they might be discriminatorily applied. ${ }^{13}$ The Court's position in these cases, attributable in part to the fact that the relief generally requested was registration under the standards rather than invalidation of them, ${ }^{14}$ has focused attention on efforts to combat voter discrimination through legislation. ${ }^{15}$

hypothesis-that those who are deprived of other rights tend not to excrcise the voting right from which the others flow, even when they are free to do so.

Id. at 13.

9. No person shall be registered as an elector of this State or be allowed to vote in any election herein, unless he be able to read and write any section of the constitution of the State of Oklahoma; but no person who was, on January 1,1866, or at any time prior thereto, entitled to vote under any form of government, or who at that time resided in some foreign nation, and no lineal descendant of such person, shall be denied the right to register and vote because of his inability to so read and write sections of such constitution.

Okla. Const. amendment (1910) quoted in Guinn v. United States, 238 U.S. 347, 357 (1915). See Myers v. Anderson; 238 U.S. 368, 377 (1915).

10. See Lane v. Wilson, 307 U.S. 268 (1939). Although its grandfather clause was struck down, Oklahoma sought to achieve the same result by requiring re-registration only of those who had not already registered under the now invalid grandfather clause, and perpetually disenfranchising those who did not register within a 12 day period. Under this provision, Oklahoma denied registration in 1934 to a Negro who could have registered but did not do so during the 12 day period in 1916.

11. See 1959 Commission Report 42-51.

12. In Davis v. Schnell, 81 F. Supp. 872 (S.D. Ala. 1949), aff'd per curiam, 336 U.S. 933 (1949), a standard which was too vague was invalidated because, as the judge held, it was intended to be and was being used for the purpose of discrimination. The Boswell Amendment to the Alabama constitution stated that the electorate would be restricted to those "who can read and write, understand and explain any article of the constitution of the United States in the English language" and "who are of good character and who understand the duties and obligations of good citizenship under a republican form of government." Ala. Const., Amendment LV (1903), amending $§ 181$, quoted in 81 F. Supp. at 874 n.1.

13. Williams v. Mississippi, 170 U.S. 213 (1898); Lassiter v. Northampton County Board of Elections, 360 U.S. 45 (1959).

14. Cases involving unsuccessful attacks on state voting procedure tend to fall in scparate categories. Williams v. Mississippi, supra note 13, was an appeal from a murder conviction before an all white jury so constituted because the jury list was drawn from the list of eligible voters. Other suits sought civil damages for deprivation of constitutional rights. Nixon v. Herndon, 273 U.S. 536 (1927) (claim for civil damages constituted cause of action). Suits in equity seeking a court order compelling registration were defeated by Mr. Justice Holmes' argument that if the voter qualification provisions are valid, a plaintiff has no case; if they are invalid, the plaintiff cannot ask a court to register him under them. See Giles v. Harris, 189 U.S. 475, 486-87 (1903). Thus in suits in equity the constitutionality of the standards was not considered. A direct attack on a reasonable Maryland statute, which requires new residents to file notice of their intent to reside in Maryland and then 
Several bills introduced in the past session of Congress, which would equate a sixth grade education with state literacy requirements, ${ }^{10}$ clearly fall within the category of legislation which eliminates or alters state voting standards. Because the power to set voting qualifications traditionally resides in the states, ${ }^{17}$ many observers have argued that Congress does not have the power to alter valid state qualification requirements or to compel the registration of persons who do not meet these standards. ${ }^{18}$ Apparently for this reason several other plans have been cast in the form of constitutional amendments. These suggested amendments range from outlawing poll taxes ${ }^{18}$ an amendment which has been passed by Congress and has been submitted to the states for ratification-to forbidding any state to set any qualifications save those relating to age, length of residence, and legal confinement. ${ }^{20}$ Except for section 1971 (e),

actually to reside in the state for one year prior to voting, led to a swceping affirmance of the state's power to set voter qualifications. Pope v. Williams, 193 U.S. 621 (1904). This holding was re-affirmed in Lassiter v. Northampton County Board of Elections, 360 U.S. 45 (1959), in which the plaintiff flatly refused to take North Carolina's literacy test. Contrast this history with the sustained litigation leading up to the landmark: cases of Smith v. Allwright, 321 U.S. 649 (1944) (white primaries); Shelley v. Kraemer, 334 U.S. 1 (1948) (racially restrictive covenants); and Brown v. Board of Education, 347 U.S. 483 (1954) (school segregation).

15. Apart from damages to the individual, relief from a great political wrong, if done, as alleged, by the people of a State and the State itself, must be given by them or by the legislative and political department of the govermment of the United States. Giles v. Harris, 189 U.S. 475, 488 (1903) (Holmes, J.) (emphasis added). This holding was limited in Lane v. Wilson, 307 U.S. 268 (1939), where it was held that an action for damages would be entertained.

16. S. 480, 87th Cong., 1st Sess., and S. 2750 and S. 2979, 87th Cong., $2 d$ Sess. (1962). S. 2750 states a congressional finding "that literacy tests and other performance examinations have been used extensively to effect arbitrary and unreasonable denials of the right to vote" and provides that no one shall deny, on the basis of such requirements, the right to vote to anyone otherwise qualified who has completed the sixth primary grade.

17. See text at note 36 infra.

18. See note 1 supra.

19. The following proposed constitutional amendment was adopted by a two-thirds yote in the Senate on March 27, 1962, in the House on August 27, 1962, and has been submitted to the state legislatures for ratification.

\section{ARTICLE-}

Section 1. The right of citizens of the United States to vote in any primary or other election for President or Vice President, for electors for President or Vice President, or for Senator or Representative in Congress, shall not be denied or abridged by the United States or any State by reason of failure to pay any poll tax or other tax.

Section 2. The Congress shall have power to enforce this article by appropriate legislation.

U.S. Code Cong. \& Ad. News 2727 (1962).

Criticism has been leveled at the limited scope of this proposed amendment. Representztive Lindsay of New York argued "this is using a sledgehammer, a cannon, to till a gnat." N.Y. Times, August 28, 1962, p. 19, col. 4. He went on to attack "tinkering with the Constitution" for such a trivial purpose.

20. In 1959 the Commission on Civil Rights proposed a twenty-third amendment.

$$
\text { ARTICIE XXIII }
$$

SECTION 1. The right of citizens of the United States to vote shall not be denied or abridged by the United States or by any State or by any person for any cause except 
legislation actually passed by Congress can easily be included in the second category, that of providing safeguards and remedies without affecting the qualification standards provided by the states.

The Civil Rights Act of $1957{ }^{21}$ illustrates an attempt by Congress to provide procedural measures which would insure the nondiscriminatory application of state statutory voting standards. It authorized federal district courts to issue injunctions against state voting registrars upon a showing of past discrimination or reasonable grounds to anticipate discrimination against any qualified voter. ${ }^{22}$ The Attorney-General of the United States was empowered to institute injunction proceedings in the name of the United States. ${ }^{23}$ In the few times relief was sought under this statute before it was amended, ${ }^{24}$ several weaknesses became apparent. ${ }^{25}$ Local registrars, having registered all white voters who qualified under state law, could resign when threatened with a federal court injunction, ${ }^{28}$ and if no successor was appointed, it was unclear whether an injunction could issue either against a board of registrars as an entity or against the state. ${ }^{27}$

inability to meet State age or length-of-residence requirements uniformly applied to all persons within the State, or legal confinement at the time of registration or election. This right to vote shall include the right to register or otherwise qualify to vote, and to have one's vote counted.

Section 2. The Congress shall have power to enforce this article by appropriate legislation.

1959 Commission Report 144-45.

21. 71 Stat. 634 (1957), 5 U.S.C. § 295-1 \& 42 U.S.C. $\$ \S 1975$, 1975 (a)-(e), and anending 28 U.S.C. $\$ \S 1343,1861 \& 42$ U.S.C. $\$ 1971$ (1958).

22. 71 Stat. 637 (1957), 42 U.S.C. \$ 1971 (c) (1958) authorizes preventive relief whenever "any person has engaged or there are reasonable grounds to believe that any person is about to engage in any act or practice which would deprive any other person" of the right to vote if qualified.

23. Ibid.

24. United States v. Raines, 172 F. Supp. 552 (M.D. Ga. 1959); United States v. McElveen, 177 F. Supp. 355 (E.D. La. 1959); United States v. Alabama, 171 F. Supp. 720 (M.D. Ala. 1959).

25. At least one observer predicted the problems which arose:

Moreover, the device of resignation may well turn out to be an effective answer to the Attorney General's requests for injunctions. I doubt seriously that a federal court can require a man to remain in office. I also doubt that many registrars would hesitate to give up their jobs if that would maintain the status quo by barring effective injunctive relief.

Horsky, The Supreme Court, Congress, and the Right to Vote, 20 Omro ST. L.J. 549, 553 (1959).

26. United States v. Alabama, 171 F. Supp. 720 (M.D. Ala. 1959).

27. Id. at 729. 42 U.S.C. $\$ 1971$ (c) was held to only contemplate discrimination by "persons." See note 22 supra. This holding was affirmed in the Court of Appeals. United States v. Alabama, $267 \mathrm{~F} .2 \mathrm{~d} 808$ (5th $\mathrm{Cir}$. 1959). The case was remanded following passage of the Civil Rights Act of 1960, 74 Stat. 86 (1960), which amended $\$ 1971$ (c) to allow such suits to be brought against the state. United States v. Alabama, 362 U.S. 602 (1960).

Only after passage of the Civil Rights Act of 1960 has it been determined that $\S 1971$ (c) allows a district court judge to order a local registrar to register specified voters. Alabama v. United States, 304 F.2d 583 (5th Cir. 1962), aff'd per curiam, 83 Sup. Ct. 145 (1962). 
These difficulties and other problems inherent in attempting to end discrimination through the enforced cooperation of state officials 28 led Congress to consider two basic remedies. Under the Federal registrar plan,,9 which would apply to only federal elections, the Commission on Civil Rights, upon the receipt of nine or more affidavits from qualified voters of one voting unit who had been denied registration, would determine whether a pattern of discrimination existed. The Commission would certify its finding of such a pattern to the President, who at his discretion could appoint a temporary or permanent federal registrar for the voting unit. This registrar would apply state statutory standards and in general would act as much as possible like an ideal state registrar; that is, a state registrar who would not discriminate in applying state voting standards. Prior to elections he would send a list of all persons registered by him to the appropriate election officials, who under pain of fine or imprisonment would have to allow those so registered to vote. Since under this plan the federal registrar would be directed to apply the voting qualifications provided in state statutes, this proposal would not affect state voting standards and thus would not raise the constitutional problems inherent in that category of legislation.

But this proposal was not enacted. Congress instead chose the voting referee plan, ${ }^{30}$ which became Title VI of the Civil Rights Act of 1960. This act applies to both state and federal elections. The procedure provided in the act does not come into effect until after an injunction prohibiting the state registrar from discriminating has been issued pursuant to the Civil Rights Act of 1957. After the issuance of this injunction and after a court finding of a "pattern or practice" of discrimination in a particular district, it allows a district court judge or a referee appointed by him to issue a certificate stating that the voter has been declared qualified to vote. ${ }^{31}$ This qualification certificate is granted to any

28. For several examples of discriminatory tactics see United States v. Alabamn, 192 F. Supp. 677 (M.D. Ala. 1961); United States v. Raines, 189 F. Supp. 121 (M.D. Ga. 1960). See also Gomillion, Civil Democracy and the Problems of Registration and Voting of Negroes in the South, 18 LAw. Gunn REv. 149, 150 (1958).

29. See S. 2684, S. 2719, 86th Cong., 1st Sess., and S. 2783, S. 2814, 86th Cong., $2 d$ Sess. (1960). The federal registrar plan was recommended by the Commission on Civil Rights. See 1959 CoMmission Report 141-42.

30. 74 Stat. 90 (1960), 42 U.S.C. § 1971(e) (Supp. III, 1962).

31. Such a certificate has been issued in United States v. Manning, 206 F. Supp. 623 (W.D. La. 1962). No Negro has been allowed to vote in East Carroll Parish, Louisianz, since 1922. In July, 1962, the federal district court for the Western District of Louisian,, applying the federal voting referee plan, ordered the issuance of certificates declaring certain Negroes qualified to vote. The state of Louisiana sought to enjoin this action, arguing that the heart of the plan, providing that "the court . . . shall issue to each appliant so declared qualified a certificate. ..." was unconstitutional. The court rejected the state's arguments, holding that the provision is not an improper delegation of executive power to the judiciary, that issuance of registration certificates is a "case or controversy" within Article III, $\$ 2$ of the Constitution, and that the act does not invade rights reserved to the states under the tenth amendment. The plan as a whole has been attacked elsewhere with a plethora of constitutional objections. Among the more significant objections are 1) The statute leaves no discretion in a court of equity; and 2) The finding of a pattern of discrim- 
member of the race discriminated against who is found qualified to vote "under state law" and who, subsequent to the court's order forbidding discrimination, has either been refused the chance to register or has been found not qualified to vote by the state registrar. The statute further provides that refusal of election officials to allow a certificate holder to vote constitutes contempt of court.

Although the act directs the federal court or referee to issue a certificate only to applicants found "qualified under State law to vote," section 1971(e) expressly provides its own definition of this phrase:

[T] he words "qualified under State law" shall mean qualified according to the laws, customs, or usages of the State, and shall not, in any cucut, imply qualifications more stringent than those used by the persons found ... [ to have discriminated] ... in qualifying persons other than those of the race or color against which the pattern or practice of discrintination was found to exist. ${ }^{\mathbf{2}}$

Assuming state law provides an ascertainable qualification standard, ${ }^{\text {sa }}$ the state registrar authorized to enforce the state registration statute may discrim-

ination is a supplemental finding to the case at bar and hence a non-judicial function: Sec United States v. Raines, 203 F. Supp. 147 (M.D. Ga. 1961).

The current administration's anticipated 1963 civil rights bill may be subject to attack on a similar basis. See The Wall Street Journal, Feb. 18, 1963, p. 1, col. 1.

A key provision of the Kennedy voting bill would require a judge to name a Federal registrar immediately after the Government certified that a significant percentage of voting-age Negroes in any community had been denied the right to vote. This would eliminate the need for a court finding of systematic discrimination and presumably would remove the judge's discretion in the matter; he would have to appoint a FedIbid. eral registrar or act in that role himself, merely on the Government's application.

Assuming that the bill requires a federal judge, who has no discretion in the matter, to appoint a registrar merely upon certification of an unchallengeable factual determination made by the executive branch of the government, it might well be unconstitutional. This appears to be a clear case of a legislative attempt to impose a nonjudicial function upon the judiciary. See Hayburn's Case, 2 U.S. (1 Dall.) 408 (1792).

The objective of the administration's bill is to speed up the process of the federal referco plan, particularly in the appointment of the federal voting official. Such an objective could be accomplished by a plan similar to the federal registrar plan. See note 29 supra and accompanying text. This plan works entirely through the executive branch and would not be subject to the aforementioned constitutional attack.

Moreover, aside from the question of improper delegation, this proposal in eliminating the need for a finding of systematic discrimination before the appointment of a federal referee raises constitutional questions identical with those posed by the federal voting referee plan. This assumes, of course, that the proposed act, like the federal voting referce plan, requires the referee to apply a standard different from state statutory law. The ab. sence of a finding of systematic discriminatory application of these statutory stanclards would render the rationale proposed in: this Note for holding the federal referee plan constitutional inapplicable. Thus, this proposed act may require a constitutional decision on whether Congress car modify state voting standards that have not been proven to be invalid. See text at notes $55-70$ infra.

32. 74 Stat. 92 (1960), 42 U.S.C. \& 1971 (e) (Supp. III, 1962) (emphasis added).

33. An unascertainable standard would be invalid. Davis v. Schnell, 81 F. Supp. 872 (S.D. Ala.), aff'd per curiam, 336 U.S. 933 (1949). 
inate in its use by either applying a higher standard to Negro applicants than that provided in the state statute or a lower standard to white applicants, or by a combination of both methods. In any case in which the state registrar has applied a lower standard to whites than the state statute requires, the direction of section 1971(e) that the court apply the registrar's standard will result in requiring a federal judge or referee to issue qualification certificates declaring the persons named qualified to vote when, in fact, the applicants were qualified by means of a lower standard than the state statute requires. ${ }^{3 t}$ To the extent that section 1971(e) alters the state statutory standard, it ceases to be wholly within that category of legislation which merely provides procedural safeguards against discrimination and, for the first time, raises the constitutional problems common to the category of legislation that would affect state qualification standards.

The reasoning underlying the constitutional objections to this category of legislation has not been fully articulated, ${ }^{35}$ but would seem to be based on the long-accepted proposition that the right to vote, at least in state elections, emanates from the states. ${ }^{38}$ Although Congress may have some power to affect voting qualifications in federal elections, ${ }^{37}$ as to state elections only the right to be exempt from discrimination comes from the federal Constitution. ${ }^{38}$ The fourteenth amendment empowers Congress to pass appropriate legislation to prevent denial of equal protection of the laws; the fifteenth amendment empowers Congress to pass appropriate legislation to ensure that the right to vote shall not be denied on account of race. Therefore, any attempt by Congress to alter state voting standards for state elections is valid only if it can be classified as "appropriate legislation" under the fourteenth or the fifteenth amendment. In section 1971 (e), the voting standard adopted indicates that the purpose of Congress was

34. The state's standard would be the state qualification statute as applied by registrars throughout the state. The local registrar's standard would be the standards he actually demands of white applicants. For factors which would be relevant in determining these standards see United States v. MIcElveen, 180 F. Supp. 10 (E.D. La. 1960) (Negroes purged from voting lists for defects in application form present in $50 \%$ of the white voters' applications) ; United States v. Alabama, 192 F. Supp. 677 (AI.D. Ala. 1961) (court named certain white voters who had received assistance filling out application forms); Byrd v. Brice, 104 F. Supp. 442 (W.D. La. 1952) (extremely low standard applied to white applicants).

35. But see note 1 supra.

36. E.g., McPherson v. Blacker, 146 U.S. 1, 35 (1892) ; Míason v. Mfissouri, 179 U.S. 328, 335 (1900) ; Breedlove v. Suttles, 302 U.S. 277, 283 (1937). But cf. United States v. Classic, 313 U.S. 299, 314-15 (1941) ; Ex parte Yarbrough, 110 U.S. 651, 663-64 (1884), which hold that although the federal constitution adopts state qualifications for congressional electors, the right to vote in federal elections comes from the federal constitution.

37. The Times, Places, and Manner of holding Elections for Senators and Representatives, shall be prescribed in each State by the Legislature thereof; but the Congress may at any time by Law make or alter such Regulations, except as to the Places of chusing Senators.

U.S. Const. art. I, § 4. See also note 36 stpra. But see Comment, Congressional Authority to Restrict the Use of Literacy Tests, 50 CALIF. L. REv. 265, 270-71 (1962).

38. See, e.g., United States v. Cruikshank, 92 U.S. 542, 555-56 (1876) ; Pope v. Williams, 193 U.S. 621, 632 (1904). 
to ensure the registration of Negro voters on an equal basis with white voters, rather than the more limited objective of registering all Negro voters qualified under a reasonable interpretation of state law. ${ }^{30}$ In determining whether this is "appropriate" legislation under the fourteenth or the fifteenth amendments, 40 the means chosen-the application in certain instances of a standard lower than the state standard-must be examined in the context of an attempt to achieve a clearly constitutional end.

The interpretation in $E x$ parte Virginia ${ }^{41}$ of the power of Congress to pass "appropriate legislation" under the fourteenth and the fifteenth amendmentsthat "whatever legislation is . . . adapted to carry out the objects the Amendments have in view ... if not prohibited, is brought within the domain of congressional power"42_makes it clear that the "appropriate legislation" clause in these amendments is to be construed in the same manner as the "necessary and proper" clause. ${ }^{43}$ In $M c C u l l o c h$ v. Maryland, 44 the Supreme Court, interpreting the necessary and proper clause broadly, established the principle that if the end is constitutional, means "which are plainly adapted to that end"46 and "which are not prohibited" 46 will generally be upheld. The interests alleged to be infringed upon by the congressional exercise of power in that case were those of federalism. And generally in other cases where the only competing interests were alleged interferences with the power of the states, the Court has afforded a large area of discretion to Congress to choose the means of achieving a constitutional end. ${ }^{47}$

39. The testimony of then Attorney-General Rogers, who was urging the passage of the federal referee plan, indicates otherwise.

I am sure the district judge will lean over backwards to be sure that anybody who is certified and qualified to vote will be fully qualified under state law.

Hearings on S. 435, S. 456, S. 499, S. 810, S. 957, S. 958, S. 959, S. 960, S. 1084, S. 1109, S. 1277, S. 1848, S. 1998, S.2001, S. 2202, S. 2003, and S. 2041, Before the Subcommittec on Constitutional Rights of the Senate Committee on the Judiciary, 86th Cong., 1st Sess., pt. 5 , at 55 (1959).

This seems contrary to the clear mandate of the act. See text at note 32 stipra. If Congress merely wished to register qualified voters under state law, as opposed to under the local standard, the federal refree plan would have incorporated the state standard, as indeed the federal registrar plan did. See text at note 29 supra.

40. See Heyman, Federal Remedies for Voteless Negroes, 48 CAurr. L. REv. 190, 206 (1960), for a short assertion of the constitutionality of $\$ 1971$ (e) under the fifteenth amendment.

41. 100 U.S. 339 (1879).

42. Id. at $345-46$.

43. The Congress shall have Power ... To make all Laws which shall be necessary and proper for carrying into Execution the foregoing Powers, and all other Powers vested by this Constitution in the Government of the United States, or in any Department or Officer, thereof.

U.S. CoNsT. art. I, \& 8.

44. 17 U.S. (4 Wheat.) 316 (1819).

45. Id. at 421 .

46. Ibid.

47. See, e.g., United States v. Hall, 98 U.S. 343, 346 (1878); Ex parte Yarbrough, 110 U.S. 651,658 (1884). 
However, the recent decision in Kinsella v. United States ex rel. Singleton 18 may indicate a willingness on the part of the Court to scrutinize the necessity and propriety of congressional means. In that case, one of a series of cases involving the limits of military court-martial jurisdiction, ${ }^{10}$ the Court struck down a congressional attempt to have civilian dependents of military personnel tried by court martial. The government argued that jurisdiction should be upheld as a necessary and proper incident of its constitutional power to "make Rules for the Government and Regulation of the land and naval Forces."50 The court refused to so read the necessary and proper clause:

If the exercise of the power is valid it is because it is granted in Clause 14, not because of the Necessary and Proper Clause. The latter clause is not itself a grant of power, but a caveat that the Congress possesses all the means necessary to carry out the specifically granted "foregoing" powers of section 8 "and all other powers vested by this Constitution. . . ."

A contrary holding here would have deprived civilian dependents of military personnel of rights secured by the federal Constitution such as the right to a jury trial.

The legislation struck down in Kinsella may be distinguished from section 1971 (e), since that legislation affected other rights afforded by the federal Constitution. The only interests affected by section 1971(e) are those of federalism. But if Kinsella is not limited to situations where the exercise of power under the necessary and proper clause conflicts with other constitutional provisions, then the approach of the Court in that case to the necessary and proper clause has a broader applicability. Under that approach, the availability of another method, which would not affect state voting standards, of achieving the same end contemplated by section 1971(e)-the registration of Negro voters on an equal basis with white voters-would seem to be a significant factor in determining whether section $1971(\mathrm{e})$ is an "appropriate" means of achieving this end.

Such a method could be derived from current provisions of section 1971 with some minor additions: local registrars could be enjoined from registering white voters who fail to meet the state statutory standard, 52 and the federal referee plan could then incorporate the same statutory standard with no resulting inequality against Negro applicants. In the event of indeterminate or long-

48. 361 U.S. 234 (1960).

49. United States ex rel. Toth v. Quarles, 350 U.S. 11 (1955); Kinsella v. Kruegar, 351 U.S. 470 (1956) ; Reid v. Covert, 351 U.S. 487 (1956); Grisham v. Hagan, 361 U.S. 278 (1960); McElroy v. United States ex rel. Guagliardo, 361 U.S. 281 (1960).

50. Kinsella v. United States ex rel. Singleton, 361 U.S. at 237.

51. 361 U.S. at 247. See also United States ex rel. Toth v. Quarles, 350 U.S. 11 (1955), which holds that the determination of the scope of legislative power to authorize trial by court-martial calls for "the least possible power adequate to the end proposed." Id. at 23 (quoting Anderson v. Dunn, 19 U.S. (6 Wheat.) 204, 230-31 (1821)).

52. The device of resignation by the state registrar, see notes $25-26$ sipra, would not be effective since the registrar presumably wants to register all possible white voters. Resignation would prevent registration of white voters; Negro applicants could be registered by the district court. 
term state registration periods, unqualified white voters already registered could be removed by court orders compelling re-examination of all registered voters within a reasonable stated time; such orders would be justified by the equal protection clause. This plan would in no way alter state voter qualifications; indeed, it would insure strict compliance with the state statutory standard.

Given the possibility of a narrow construction of "appropriate" as that term is used in the fourteenth and the fifteenth amendments, and the widespread belief that federal legislation establishing qualifications for voters is beyond the power of Congress, ${ }^{53}$ the existence of this purely procedural means of reaching the same end casts doubt upon the validity, under the fourteenth or the fifteenth amendment, of this congressional effort to combat voter discrimination. These doubts warrant a closer examination into what Congress has actually done in directing the federal courts to certify voters who meet the standard actually applied by the state registrar to the preferred group. If this legislation does not in fact alter valid state requirements, it would fall into the category of legislation providing procedural safeguards against voter discrimination. Such a finding would obviate the necessity of an examination of the limits of congressional power directly to affect state voting standards, an examination which would be exceedingly important in regard to proposed legislation like the sixth grade literacy bills. The federal referee plan, primarily a procedural remedy, may not present a case properly framed or properly timed for deciding an issute which has such far reaching implications in our federal system. Legislation such as the literacy bill would seem to better and more directly pose the question of Congress' power in this area than the federal referee plan. Indeed, a decision on this question in relation to section 1971(e) might simply evoke "prematture echoes"54 that would prove troublesome in considering later, more diffictult cases. Thus, even if section 1971(e) can be sustained as an appropriate means to achieve the ends of the fourteenth and the fifteenth amendments, another avenue of decision, which would permit the Court to avoid having to define the limits of congressional power to establish federal voting qualifications or to change state ones, would seem advisable. ${ }^{55}$

The problem of justifying the alteration of state standards would disappear if the registrar's standard could be considered determinative of state law. It is established that a state standard, to be valid, must be ascertainable ; ${ }^{50}$ thus, when a state registrar applies a lower standard than that provided in a reasonably definite state statute, he may be acting under color of state law, but he is at the same time acting in violation of such law. To equate his illegal activity

53. See note 1 supra.

54. Pollak, The Supreme Court and the States: Refections 8n Boynton v. Virginia, 49 CAIIF. L. Rev. 15, 40 (1961).

55. Judicial authority to select the most apt of several possible avenues of decision is a sensitive and a powerful weapon. Utilized with sophistication, it complements the Supreme Court's broad discretion as to which cases the Court will entertain, and in Id. at 17 . what sequence.

56. See note 12 supra. 
with state law would require an application of the "under color of state law" doctrine-which attributes to the state actions of its officials ${ }^{57}$-in a setting quite different from its original context. The doctrine has traditionally been used to provide a federal remedy for one whose constitutional rights have been violated by the unlawful actions of a state official $; 58$ it should not be used, against a proper standard asserted by the state, as a conclusive definition of what constitutes state law. To do so would allow the unlawful actions of a state official to alter or modify state law duly promulgated by state legislatures and interpreted by its courts for purposes other than relief in an individual case. The state's argument that its registrar's actions does not constitute state law is strengthened where it provides a remedy for the improper application of its registration statute by the local registrar. In Louisiana, for example, any two registered voters can challenge the qualifications of any other registered voter. ${ }^{50}$ Thus the inclusion of the registrar's standard in the federal referee plan cannot be justified by the assumption that the registrar's standard determines the lawful state standard. Since the standard Congress has incorporated in the federal referee plan is not the lawful state standard, section 1971(e) would still appear to alter state law.

But this conclusion rests upon the proposition that there is a valid state statute providing standards for the registration of voters. This proposition in turn assumes that the consistent discriminatory application of a voting statute by a local registrar does not in any way affect the validity of the statute. Voter registration statutes have been held to be constitutionally infirm only when an invidious discriminatory purpose is apparent on the face of the statute, as exemplified by the grandfather clauses, ${ }^{60}$ or when the criteria provided are so vague as to confer unfettered discretion on a state official, such as a requirement that only persons of good character can vote. ${ }^{01}$ Constitutional guarantees against discrimination wholly invalidate such statutes. Where a state statutory requirement is not subject to invalidation on those grounds, challenges to the statute based upon a particular discriminatory application would result in a holding that the action taken under the statute is unconstitutional. The statute itself, however, would remain unaffected by such a holding. But the Supreme Court's decision in Yick Wo v. Hopkins ${ }^{62}$ indicates that a challenge to official action based upon a history of discriminatory application taken under an apparently nondiscriminatory statute may have further reaching effects than a mere invalidation of the official's action in a particular case. In that case, a San Francisco ordinance required the licensing of all laundries operated in wooden

57. See Monroe v. Pape, 365 U.S. 167 (1960).

58. Ibid.

59. LA. Rev. Stat. tit. 18, § 245 (1952) allows two registered voters, "after reasonable investigation and on information and belief certain persons are illegally registered," to challenge by written affidavit such persons' registration.

60. See note 9 supra.

61. See note 12 supra.

62. 118 U.S. 356 (1886). 
buildings. Licenses were systematically granted to all but Chinese laundrymen. Yick Wo was convicted of violating the ordinance by operating without a license and was sent to jail for nonpayment of the fine. The Supreme Court, in directing his discharge on a writ of habeas corpus, declared:

In the present cases, we are not obliged to reason from the probable to the actual, and pass upon the validity of the ordinances complained of, as tried merely by the opportunities which their terms afford, of unequal and unjust discrimination in their administration. For the cases present the ordinances in actual operation, and the facts shown establish an administration directed so exclusively against a particular class of persons as to warrant and require the conclusion, that, whatever may have been the intent of the ordinances as adopted, they are applied by the public authorities charged with their administration, and thus representing the State itself, with a mind so unequal and oppressive as to amount to a practical denial by the state of that equal protection of the laws which is secured to the petitioners, as to all other persons, by the broad and benign provisions of the Fourteenth Amendment to the Constitution of the United States. Though the law itself be fair on its face and impartial in appearance, yet, if it is applied and administered by the public authority with an evil eye and an unequal hand, so as practically to make unjust and illegal discriminations between persons in similar circumstances, material to their rights, the denial of equal justice is still within the prohibition of the Constitution. ${ }^{63}$

The application of the equal protection clause in the $Y i c k W o$ case resulted in the condemnation of discriminatory executive action taken under an ordinance nondiscriminatory on its face. ${ }^{64}$ This discrimination occurred in the issuance of licenses; Yick Wo was sent to jail for operating without a license. In order to release him from jail, the Supreme Court had to conclude that the requirement that Yick Wo have a license to operate was invalid because of the pattern of discriminatory issuance of licenses which had been demonstrated. The ordinance

63. Id. at 373-74.

64. The decision in the Yick $W o$ case may be explained as a necessary consequence of the vagueness of the ordinance.

It lays down no rules by which its impartial execution can be secured or partiality and oppression prevented.

Yick Wo v. Hopkins, 118 U.S. at 372-73 (1886), quoting City of Baltimore v. Radecke, $49 \mathrm{Md} .217,230$ (1878) (emphasis in original).

The decision can be explained as a consequence of the unconstitutional motive of the city of San Francisco in passing the ordinances.

The seem intended to confer . . . a naked and arbitrary power to give or withhold consent....

118 U.S. at 366 (emphasis added).

The case may be considered the result of the extensive discretion given the supervisors. The power given to them . . . is granted to their mere will. It is purely arbitrary, and acknowledges neither guidance nor restraint.

Id. at 366-67.

The general theory of the Yick Wo case is that constitutional guarantees will invalidate discriminatory action taken under an otherwise valid and non-discriminatory law. See text at note 63 supra. See, e.g., Snowden v. Hughes, 321 U.S. 1, 8 (1944); Lassiter v. Northampton County Board of Elections, 360 U.S. 45, 50 (1959). 
requiring a license to operate was not declared unconstitutional ;05 nor was the question of whether the ordinance could be used to prevent other persons from operating laundries in wooden buildings decided. Nevertheless the effects of the Court's decision is that the ordinance cannot be constitutionally enforced against Yick Wo or any other person who was discriminated against in the issuance of licenses. For any proceeding to impose sanctions upon such persons for operating without licenses would be invalidated because of the pattern of discriminatory issuance that was demonstrated in Yick Wo. This leads to the conclusion that the validity of this ordinance cannot be asserted in any judicial proceeding until applied in a manner not prohibited by the fourteenth amendment-until, in effect, it is purged of its unconstitutionality. In the Yick Wo case, this could only be accomplished by a nondiscriminatory relicensing of all wooden laundries, since allowing those licensed under the discriminatory procedure to remain licensed would perpetuate the past discriminatory executive action which was the basis for the result in $Y i c k W 0 .^{68}$ Thus, although the ordinance is not completely invalidated because of the manner of its enforcement, it is constitutionally infirm to the extent that its enforcement violates the federal constitution until the state revokes all outstanding licenses and proceeds to issue them impartially.

This experience under $Y i c k$ Wo demonstrates that a pattern of discriminatory executive action taken under a nondiscriminatory statute may render requirements of that statute constitutionally invalid. ${ }^{\text {if }}$ In any proceeding under section 1971(e) evidence of systematic discrimination is necessarily present, as that provision does not go into effect until a federal district court has made a

65. See Note, The Void-For-Vagueness Doctrine In the Supreme Court, 109 U. PA. L. REv. 67, 111-14 (1960), for an analysis of the $Y i c k$ Wo case in terms of vagueness. That commentator considered the effect of the decision on the San Francisco ordinance.

[I]t would have been competent for the San Francisco supervisors to continue enforcement of its wooden laundry regulation after Yick Wo provided that they manage to avoid any (judicially provable) discrimination.

109 U. PA. L. REv. at 113.

66. Such a result would be comparable to the denial of equal protection condemned in Lane v. Wilson, 307 U.S. 268 (1939). See note 10 supro.

67. The Yick Wo doctrine has not been relied upon in prior cases involving discrimination in registration. In general an attack on the state standard was incidental as the parties asked for a court order compelling registration or civil damages for a denial of constitutional rights. See, e.g., Giles v. Harris, 189 U.S. 475 (1903). Some litigants did not prove actual discrimination. In one case the Supreme Court specifically refused to apply the Yick $W_{0}$ doctrine to state standards, stating that it was

not applicable to the constitution of Mississippi and its statutes. They do not on their face discriminate between the races, and it has not been shown that their actual administration was evil, only that evil was possible under them.

Williams v. Mississippi, 170 U.S. 213, 225 (1898). But see Byrd v. Brice, 104 F. Supp. 442 (W.D. La. 1952), aff'd, 201 F.2d 664 (5th Cir. 1953). A district court judge, relying in part upon the $Y i c k$ Wo case, enjoined a registrar from discriminating against Negro applicants. There were 9,000 registered white voters and no registered colored voters.

See also note 14 supra and accompanying text. 
finding that a deprivation of voting rights has occurred and that this deprivation was pursuant to a "pattern or practice" of discrimination. In Yick Wo the requirement rendered invalid because of systematic discrimination was the necessity of a license to operate. Where the local registrar applies a lower standard to white applicants than the state registration statute provicles, the requirements rendered invalid would be those provisions of the statute that have not been applied as written to the preferred group. So long as members of the preferred group remain registered to vote, after being registered in accordance with the lower standard, the application of these statutory requirements to Negro applicants would clearly constitute a denial of equal protection of the law. These provisions would continue to be unenforceable until, in effect, they are purged of their unconstitutionality. As in the $Y i c k W o$ case, this could only be achieved by revoking the registration of those applicants who, by not being required to fulfill these statutory standards, were qualified under a dis* criminatory procedure. Because these provisions of the state voting registration statute are unenforceable when the local registrar has systematically used a lower standard for white applicants, Congress can hardly be said to have altered state law in this situation by directing the federal courts not to use the statutory standard in registering Negro applicants who have been discriminated against.

Although Congress has not altered a state standard in qualifying applicants by means of a lower standard when the state statutory provisions are in fact unenforceable, the source of congressional power to set any standard for voter qualification must be examined. Once it is recognized that the state statutory standards are, in effect, invalid because of their discriminatory application, the congressional requirement that the district court qualify all Negro applicants who are eligible to vote under the local registrar's standard is clearly an "appropriate" remedy under the fourteenth and the fifteenth amendments. The requirements of the state registration statute which have not been discriminatorily applied remain valid and thus constitute an enforceable state standard which is less stringent than the local registrar's, since it does not include any of the requirements the registrar has misapplied. Congress could probably have provided for the registration of all Negro applicants who fulfill only those state statutory requirements that remain enforceable. But this would seem unfair to white applicants, who have no access to the federal referee plan, which only qualifies members of the group discriminated against. ${ }^{88}$ On the other hand, congressional use of any standard higher than that applied by the local registrar to white applicants would perpetuate the past discrimination, since all white voters already qualified in relation to the lower standard would remain registered. Thus, in the absence of an enforceable state standard higher than that used by the local registrar, Congress' use of the registrar's standard would seem to be the most "appropriate" means to remedy the denial of equal protection forbid-

68. 74 Stat. 90 (1960), 42 U.S.C. \& 1971 (e) (Supp. III, 1962) provides that only a person of the "race or color" discriminated against is entitled to an order declaring him qualified to vote. 
den by the fourteenth amendment and the denial of the right to vote on account of race condemned by the fifteenth amendment.

Moreover, the appropriateness of section 1971(e) is further demonstrated by the fact that Congress has in no way deprived the states of the power to reestablish the validity of those standards rendered unenforceable and to require that all voters, including those certified under the federal referee plan, meet their requirements so long as those requirements are impartially applied. Congress provided that a federal order of qualification

shall be effective as to any election held within the longest period for which such applicant could have been registered or otherwise qualified under State law at which the applicant's qualifications would under State law entitle him to vote. ${ }^{69}$

This indicates that the state, by revoking all registrations and requiring complete re-registration of all voters, could terminate the federal qualification orders. It could then proceed to register Negro as well as white voters, in accordance with standards established by the state legislature and without any federal interference. Lack of discrimination in the new registration procedure would render the federal referee plan totally inoperative. ${ }^{70}$

The recent case of United States $v$. Penton ${ }^{71}$ graphically illustrates the desirability of applying the rationale of Yick $W o$ to state voting requirements which have been applied in a discriminatory manner. In this case Judge Johnson, after hearing the oral testimony of over 175 witnesses and after examining approximately 13,000 exhibits, concluded that the registrars of Montgomery County, Alabama, had been using a statutory requirement-that a registration questionnaire be filled out "in the presence of the board without assistance"72 - in a discriminatory manner. ${ }^{73}$ For the period from January 1, 1956 through June 16, 1961, an average of 75.4 per cent of Negro applicants were rejected compared to an average rejection of 3.4 per cent of the white applicants.

Of these rejected Negroes, 6 had master's degrees; 152 had four years of college training, and 222 had some college education. This group of rejected Negroes included 108 Negro public school teachers. ${ }^{74}$

The court found that for white applicants the questionnaire had been used "merely as a method to obtain substantive information concerning the applicants' qualifications."75 However, for Negro applicants it was used, in addition,

69. Ibid.

70. The federal referee plan provides that the court, after $a$ finding of a pattern or practice of discrimination, shall continue to entertain applicants for qualification orders for one year and thereafter until the court subsequently finds that such pattern or practice has ceased.

Ibid.

71. Civil Action No. 1741-N (M.D. Ala 1962).

72. 17 Ala. Stat. \& 31 (1940).

73. See Marshall, Federal Protection of Negro Voting Rights, 27 Lav \& Coxtzan. ProB. 455, 462-63 (1962).

74. United States v. Penton, Civil Action No. 1741-N (MI.D. Ala. 1962) at p. 3.

75. Id. at 5 . 
"as a tricky examination or test."76 Most white applicants were given assistance with the questionnaire if they requested it. Technical errors in filling out the questionnaire were disregarded if the applicant was white, but became the basis for rejection if the applicant was a Negro. A question asking for length of residence in the state, county and precinct was regularly filled in for white voters from oral information; Negroes were given no assistance. Negroes who were not informed that they must sign a printed oath were rejected for not doing so. Judge Johnson made detailed findings as to the standard applied by the local registrar to white applicants. In addition to ordering the registration of several hundred named Negroes found qualified in relation to this standard during the course of the trial, ${ }^{77}$ he declared

It is further ORDERED, ADJUDGED and DECREED that said defendants are enjoined from using ... different and more stringent qualification requirements for registration in Montgomery County, Alabama, than (those) used by the Board of Registrars of Montgomery County since at least January $1,1956 .^{.78}$

He also enjoined the registrars from rejecting any applicant for failure to fill out the residence question correctly, for failure to sign the oath unless the applicant refuses, or for "technical or inconsequential errors or omissions." The court stated that the determination of the local registrars' actual standard

will facilitate registration under the federal referee provisions of the Civil Rights Act if future conduct by the defendants makes this course necessary. ${ }^{79}$

If the Yick Wo doctrine is applied to the state statutory standard in this case, the judge's order is viewed merely as an injunction forbidding enforcement of state requirements which have been rendered invalid because of their past discriminatory application. The order prevents future denials of equal protection by requiring that Negro applicants be judged by the same standards used in qualifying those persons already registered. If, despite the proven discrimination in application, and despite the fact that those registered under this discriminatory procedure remain registered, the state standard remains valid, Judge Johnson's decree must be viewed as a federal court order compelling a state official to continue to violate state law.

Although the Penton case arises under the Civil Rights Acts of 1957 and 1960, the particular remedy granted in that case-the injunction requiring the state registrar to apply the lower standard to Negroes-is not explicitly attthorized by either of these acts. ${ }^{80}$ But this would not seem to be a bar to the

76. Ibid.

77. See Alabama v. United States, 304 F.2d 583(5th Cir.), aff'd per curiam, 83 Sup. Ct. 145 (1962). A district court order compelling the state registrar to register named Negro applicants was upheld.

78. United States v. Penton, Civil Action No. 1741-N (M.D. Ala. 1962), Decrce, p، 2

79. United States v. Penton, supra note 78, at 10.

80. 71 Stat. 637 (1957), 42 U.S.C. \$ 1971(c) (Supp. III, 1962) authorizes the Attorney General of the United States, upon proof of past discrimination or a showing of reasotr able grounds for future discrimination, to institute a proper proceeding for 
court's action in this case. For the rationale of the Yick Wo case is a judicial doctrine which has long been available to prevent application of constitutionally infirm state statutes to those discriminated against. The availability of this traditional judicial doctrine indicates that congressional legislation was not a prerequisite to judicial action; the presumed bar to such action, the fact that a state standard was nondiscriminatory on its face, was illusory. Willingness to invalidate state standards upon proof of a pattern of discriminatory executive action taken under them would allow the judiciary to meet future and more subtle attempts to discriminate, lessening dependence on Congress for effective remedies. The Supreme Court has stated, through Mr. Justice Frankfurter, that constitutional prohibitions against voter discrimination nullify sophisticated as well as obvious methods of discrimination. ${ }^{81}$ The question of whether section 1971 (e) alters state voting standards, or whether it in reality falls in the category of purely procedural legislation, affords an opportunity for the application of the Yick Wo doctrine to these standards. This opportunity should indicate how sophisticated the federal judiciary is prepared to be in the area of voter discrimination.

preventive relief, including an application for a permanent or temporary injunction, restraining order, or other order.

Section 1971(d) confers jurisdiction upon United States district courts to entertain such proceedings.

81. Lane v. Wilson, 307 U.S. 268 (1939). 